\title{
Pengembangan lembar kerja siswa dengan menggunakan pendekatan penemuan terbimbing untuk siswa SMP pada materi luas permukaan dan volume bangun ruang sisi lengkung
}

\author{
Dewi Ratna Ayu Wulaningrum, Rini Nurhakiki* \\ Universitas Negeri Malang, Jl. Semarang No. 5 Malang, Jawa Timur, Indonesia \\ *Penulis korespondensi, Surel: rini.nurhakiki.fmipa@um.ac.id
}

Paper received: 01-11-2021; revised: 15-11-2021; accepted: 30-11-2021

\begin{abstract}
Based on the observations made when PPL in SMP Negeri 21 Malang, students used worksheets that have the look monotonous and only contains a summary of the material and the questions. The aim of this development is to develop worksheets for surface area and volume of material with curved side using guided discovery. Development of student worksheets surface area and volume of material with curved side using guided discovery pendekatanl was developed by adapting the model Plomp. In developing learning media composed into five phases: (1) the initial investigation phase, (2) the design phase, (3) the realization phase / construction, (4) the test phase, evaluation, and revision (5) the implementation phase. Based on the results of the validation and field trials student worksheets developed by the percentage of 75.78 percent valid, practically with the percentage of 87.5 percent, and said to be invalid because the evaluation value obtained by six students meet the minimum passing criteria given is 75 .
\end{abstract}

Keywords: student worksheets; guided discovery; surface area and volume curved side

\begin{abstract}
Abstrak
Berdasarkan hasil observasi yang dilakukan ketika PPL di SMP Negeri 21 Malang, LKS yang digunakan siswa memiliki tampilan yang monoton dan hanya berisi rangkuman materi dan soalsoal. Tujuan dari pengembangan ini adalah mengembangkan LKS untuk materi luas permukaan dan volume bangun ruang sisi lengkung dengan menggunakan pendekatanl penemuan terbimbing. Pengembangan lembar kerja siswa materi luas permukaan dan volume bangun ruang sisi lengkung dengan menggunakan pendekatanl penemuan terbimbing ini dikembangkan dengan mengadaptasi model Plomp. Dalam mengembangkan media pembelajaran terdiri menjadi lima fase yaitu : (1) fase investigasi awal, (2) fase desain, (3) fase realisasi/konstruksi, (4) fase tes, evaluasi, dan revisi (5) fase implementasi. Berdasarkan hasil validasi dan uji coba lapangan lembar kerja siswa yang dikembangkan valid dengan persentase 75,78 persen, praktis dengan persentase 87,5 persen, dan dikatakan valid karena nilai evaluasi yang didapatkan oleh enam siswa memenuhi kriteria kelulusan minimal yang diberikan yaitu 75 .
\end{abstract}

Kata kunci: lembar kerja siswa; pendekatan penemuan terbimbing; luas permukaan dan volume bangun ruang sisi lengkung.

\section{Pendahuluan}

Berdasarkan hasil observasi ketika PPL di SMP Negeri 21 Malang banyak siswa yang tidak tahu bagaimana rumus untuk menghitung luas permukaan dan volume bangun ruang sisi lengkung dapat diperoleh. Selain itu, LKS yang digunakan dalam pembelajaran memiliki tampilan yang monoton dan hanya berisi rangkuman materi dan soal-soal sehingga siswa kurang memiliki kesempatan untuk dapat mengkonstruksi pemahaman mengenai konsep materi dan hanya menghafal rumus yang ada. 
Salah satu media pembelajaran yang digunakan siswa dalam kegiatan belajar mengajar adalah LKS. Melalui LKS siswa dapat belajar secara mandiri untuk menambah informasi mengenai suatu konsep tentang materi yang dipelajari.

Model pembelajaran dengan penemuan terbimbing mendorong siswa untuk berpikir sendiri sehingga dapat menemukan prinsip umum berdasarkan bahan yang disediakan oleh guru dan sampai seberapa jauh siswa dibimbing tergantung pada kemampuannya dan materi yang sedang dipelajari. Tujuan dari pengembangan ini adalah menghasilkan LKS untuk materi luas permukaan dan volume bangun ruang sisi lengkung dengan menggunakan pendekatan model penemuan terbimbing. Langkah-langkah pemmbelajaran dengan Penemuan Terbimbing dalam Markaban (2006) adalah sebagai berikut:

1. Merumuskan masalah yang akan diberikan kepada siswa

Perumusan masalah harus jelas, hindari pernyataan yang menimbulkan salah tafsir sehingga arah yang ditempuh siswa tidak salah.

2. Siswa menganalisis dan memproses masalah yang diberikan

Dari data yang diberikan guru, siswa menyusun, memproses, mengorganisir, dan menganalisis data tersebut. Dalam hal ini, bimbingan guru dapat diberikan sejauh yang diperlukan saja. Bimbingan ini sebaiknya mengarahkan siswa untuk melangkah ke arah yang hendak dituju, melalui pertanyaan-pertanyaan, atau LKS.

3. Siswa menyusun konjektur (perkiraan) dari hasil analisis yang dilakukan

4. Siswa memeriksa kebenaran konjektur

Bila dipandang perlu, konjektur (perkiraan) yang telah dibuat siswa tersebut di atas diperiksa oleh guru. Hal ini penting dilakukan untuk meyakinkan kebenaran prakiraan siswa, sehingga akan menuju arah yang hendak dicapai.

5. Cek pemahaman

Sesudah siswa menemukan apa yang dicari, hendaknya guru menyediakan soal latihan atau soal tambahan untuk memeriksa apakah hasil penemuan itu benar.

\section{Metode}

\subsection{Model}

Pengembangan lembar kerja siswa materi luas permukaan dan volume bangun ruang sisi lengkung dengan menggunakan pendekatan model penemuan terbimbing ini dikembangkan dengan mengadaptasi model Plomp dalam Hobri (2010). Dalam mengembangkan media pembelajaran terdiri menjadi beberapa fase yaitu :

\subsection{Fase investigasi awal}

Kegiatan yang dilakukan pada fase ini terfokus pada pengumpulan dan analisis informasi, merumuskan masalah dan merencanakan kegiatan selanjutnya.

\subsection{Fase desain}


Fase ini difokuskan kepada hasil yang telah didapat dari fase investigasi awal.. Kegiatan dalam fase ini meliputi pemilihan media dan materi.

\subsection{Fase realisasi/konstruksi}

Fase ini merupakan fase produksi media yang dikembangkan dalam hal ini adalah lembar kerja siswa. Kegiatan yang dilakukan pada fase ini adalah menyusun sintaks dan memberikan gambaran umum tentang LKS yang dikembangkan.

\subsection{Fase tes, evaluasi, dan revisi}

Fase evaluasi akan menentukan apakah produk yang dikembangkan telah sesuai standart atau tidak. Kegiatan yang dilakukan pada fase ini terdiri dari dua kegiatan utama yaitu validasi dan uji coba.

\subsection{Uji Coba Produk}

Uji produk dilakukan untuk memperoleh data yang dapat digunakan sebagai dasar untuk menetapkan tingkat kevalidan, kepraktisan, serta keefektifan produk. Selain itu, untuk menghasilkan produk yang dapat digunakan oleh siswa SMP. Uji coba produk dilakukan dengan melakukan uji kevalidan produk pengembangan yang divalidasi oleh pakar matematika, yaitu dosen matematika dan guru matematika SMP. Kemudian uji coba kepraktisan dan keefektivan dilakukan oleh siswa 10 siswa SMP kelas VIII.

Tingkat kevalidan produk pengembangan diukur dengan penilaian validator dari lembar validasi. Data yang diperoleh, dianalisis menggunakan teknik analisis sebagai berikut :

$$
P=\frac{\sum_{i=1}^{n} x_{i}}{\sum_{j=1}^{n} x_{j}} \times 100 \%
$$

Keterangan:

$P$ adalah persentase tingkat kevalidan.

$\sum_{\mathrm{i}=1}^{\mathrm{n}} \mathrm{x}_{\mathrm{i}}$ adalah jumlah jawaban penilaian.

$\sum_{\mathrm{j}=1}^{\mathrm{n}} \mathrm{x}_{\mathrm{j}}$ adalah jumlah jawaban tertinggi.

Sedangkan sebagai dasar pengambilan keputusan untuk merivisi produk digunakan kriteria penilaian yang diadaptasi dari buku Dasar-Dasar Evaluasi Pendidikan oleh Arikunto.

Kriteria Kevalidan Produk Pengembangan

\begin{tabular}{|c|l|l|}
\hline Skala & Kriteria Validitas & Keterangan \\
\hline $80-100$ & Sangat Valid & Tidak Revisi \\
\hline $66-79$ & Valid & Tidak Revisi \\
\hline $56-65$ & Cukup Valid & Tidak Revisi \\
\hline $40-55$ & Kurang Valid & Revisi \\
\hline $30-39$ & Sangat Kurang Valid & Revisi \\
\hline
\end{tabular}

(Diadaptasi Arikunto, 2009 : 245) 
Selain kevalidan, uji coba produk ini juga dengan melakukan uji kepraktisan. Kepraktisan lembar kerja siswa diukur dengan penilaian angket yang diisi oleh siswa. Data yang diperoleh, dianalisis menggunakan teknik analisis sebagai berikut :

$$
P=\frac{\sum_{i=1}^{n} x_{i}}{\sum_{i=1}^{n} x_{j}} \times 100 \%
$$

Keterangan:

$P \quad$ : persentase penilaian

$\sum_{i=1}^{n} x_{i}$ : jumlah skor penilaian dari siswa

$\sum_{i=1}^{n} x_{j}$ : jumlah skor penilaian tertinggi

Sedangkan sebagai dasar pengambilan keputusan untuk merivisi produk digunakan kriteria penilaian yang diadaptasi dari buku Dasar-Dasar Evaluasi Pendidikan oleh Arikunto.

Kriteria Kepraktisan Produk Pengembangan

\begin{tabular}{|c|l|l|}
\hline Skala & Kriteria Validitas & Keterangan \\
\hline $80-100$ & Sangat Valid & Tidak Revisi \\
\hline $66-79$ & Valid & Tidak Revisi \\
\hline $56-65$ & Cukup Valid & Tidak Revisi \\
\hline $40-55$ & Kurang Valid & Revisi \\
\hline $30-39$ & Sangat Kurang Valid & Revisi \\
\hline
\end{tabular}

(Diadaptasi Arikunto, 2009: 245)

Uji coba keefektifan produk hasil pengembangan dilakukan kepada siswa kelas VII SMP. Hal ini bertujuan untuk mengukur tingkat keberhasilan produk pengembangan lembar kerja siswa yang telah dikembangkan. Untuk mengukur tingkat keefektifan produk pengembangan dilihat dari nilai soal evaluasi yang dikerjakan oleh siswa. Apabila semua nilai siswa memenuhi kriteria ketuntasan minimal yang ditentukan yaitu 75 maka lembar kerja siswa yang dikembangkan dikatakan efektif.

\section{Hasil dan Pembahasan}

Berdasarkan hasil validasi dan uji coba lapangan terhadapa lembar kerja siswa didapatkan hasil sebagai berikut :

\subsection{Uji kevalidan}

Berdasarkan hasil analisis data hasil penilaian lembar validasi oleh validator yaitu dosen matematika dan guru SMP diperoleh lembar kerja siswa yang telah dikembangkan memenuhi kriteria sangat valid dengan persentase 75,78\%

\subsection{Uji Kepraktisan}

Dari analisis data angket siswa yang dilakukan oleh 6 siswa uji coba, diperoleh lembar kerja siswa yang telah dikembangkan dikatakan praktis dengan persentase $87,5 \%$. 


\subsection{Uji keefektifan}

Dari analisis data nilai evaluasi 10 siswa uji coba, diperoleh lembar kerja siswa yang telah dikembangkan dikatakan efektif karena nilai yang didapat oleh semua siswa memenuhi kriteria kekulusan minimal yaitu 75 .

Berdasarkan analisis data hasil uji coba kevalidan, kepraktisan, dan keefektifan yang telah diuraikan di atas, dapat disimpulkan bahwa produk lembar kerja siswa dapat digunakan untuk siswa jenjang SMP dalam pembelajaran matematika.

\section{Simpulan}

Berdasarkan uji coba dapat disimpulkan LKS yang dikembangkan dikatakan valid dengan persentase $75,78 \%$. Sementara itu berdasarkan hasil uji coba dapat disimpulkan bahwa LKS yang dikembangkan dikatakan praktis dengan persentase 87,5\%. LKS yang dikembangkan dikatakan efektif karena keenam siswa mendapatkan nilai lebih dari 75 saat mengerjakan soal evaluasi. Karena memenuhi tiga kriteria yaitu valid, praktis dan efektif, maka LKS yang dikembangkan dapat digunakan sebagai alternatif bahan ajar matematika pada pokok bahasan luas permukaan dan volume bangun ruang sisi lengkung.

Adapun saran pengembangan lembar kerja siswa lebih lanjut adalah sebagai berikut :

4.1. Guru dapat memanfaatkan LKS ini sebagai alternatif bahan ajar di sekolah dan dimungkinkan untuk mengembangkan LKS ini sesuai kondisi siswa di sekolah yang bersangkutan.

4.2. Pengembangan LKS terbatas pada materi luas permukaan dan volume tabung, kerucut, dan bola. Oleh karena itu, diharapkan ada tindak lanjut pengembangan LKS dengan pendekatan penemuan terbimbing untuk pokok bahasan lainnya.

\section{Daftar Rujukan}

Arikunto, Suharsimi. (2009). Dasar-Dasar Evaluasi Pendidikan. Jakarta: Bumi Aksara.

Depdiknas. (2008). Pengembangan Bahan Ajar. Direktorat Pembinaan Sekolah Menengah Atas Direktorat Jenderal Manajemen Pendidikan Dasar dan Menengah Departemen Pendidikan Nasional.

Hobri. (2010). Metodologi Penelitian Pengembangan. Jember: Pena Salsabila.

Lentera, K. (2012, Oktober 6). Pengertian Lembar Kerja Siswa (LKS). http://lenterakecil.com/pengertianlembar-kerja-siswa-lks/

Markaban. (2006). Model Pembelajaran Matematika Dengan Pendekatan Penemuan Terbimbing. Yogyakarta: PPPG Matematika.

Mbulu, Joseph dkk. (2004). Pengembangan Bahan Ajar. Malang: Elang Mas.

Musser dkk. (2008). College Geometry A Problem-solving Approach With Application. Canada: Pearson.

Suherman, dkk. (2006). Strategi Pembelajaran Matematika Kontemporer. Bandung: Jica.

Suparno, Paul. (2001). Filsafat Konstruktivisme dalam Pendidikan. Yogyakarta : Kanisius.

Trisnawati, Rina. (2012, September 18). LKS (Worksheet). http://reenhatrisnawati.blogspot.com/2012/04/blog-post.html 